\title{
Microbiological quality analysis of raw, pasteurized, UHT milk samples collected from different locations in Bangladesh
}

\author{
Sourav Kumar Banik ${ }^{1,2}$, Kamal Kanta Das ${ }^{2}$ and Md. Aftab Uddin ${ }^{2 \ddagger}$ \\ ${ }^{1}$ Quality Control (QC) Department, Akij Food \& Beverage ltd. Krisnopura, Dhamrai-1350, Dhaka; \\ ${ }^{2}$ Department of Microbiology, Stamford University Bangladesh, 51 Siddeswari Road, Dhaka 1217, \\ Bangladesh
}

Received 13 March 2014/Accepted 11 May 2014

\begin{abstract}
Present study attempted to determine the microbiological quality of raw, pasteurized and UHT (Ultra High Temperature-processed) milk samples collected from different locations in Bangladesh. A total of 46 samples were studied including 22 raw milk samples from the local dairy markets and 24 different brands of pasteurized and ultrahigh temperature (UHT) treated milk manufactured in different beverage industries. The samples were examined for determining the total viable bacterial count (TVBC) and total coliform count (TCC). Results revealed that the raw milk samples were substandard in terms of TVBC and TCC. The range of TVBC and TCC in raw milk samples was $5.2 \times 10^{8}$ to $1.3 \times 10^{7}$ $\mathrm{cfu} / \mathrm{ml}$ and $4.2 \times 10^{4}$ to $1.0 \times 10^{4} \mathrm{cfu} / \mathrm{ml}$, respectively. On the contrary, the quality of pasteurized and UHT-treated milks was excellent. The TVBC range in pasteurized milk samples was from $1.8 \times 10^{3}$ to $1.1 \times 10^{2} \mathrm{cfu} / \mathrm{ml}$, slightly lower than that recommended by the Bangladesh Standards and Testing Institution (BSTI). Interestingly sample numbers P-6, P-10 and P-12 of pasteurized milk samples had no growth at all both in terms of TVBC and TCC and none of the UHT processed milk contained any bacteria. So from the consumer point of view, both types of processed milk can be considered safe for consumption within the mentioned expiry date.
\end{abstract}

Key words: Raw milk; Pasteurized milk; UHT milk; Microbiological quality

Milk is known to be the most complete food found in nature $(1,2)$. Milk is valuable and consumed on daily basis. As milk contains fat, protein, carbohydrates, minerals, vitamins and other various ingredients dispersed in water, it is considered as a complete diet (3). But at the same time, it is highly vulnerable to bacterial contamination and hence is easily perishable $(4,5)$.

Milk is synthesized in specialized cells of the mammary gland and is virtually sterile when secreted into the alveoli of the udder (6). Beyond this stage of milk production, microbial contamination can generally occur from the exterior of the udder and from the surface of milk handling and storage equipment. Bacterial contamination of raw milk can originate from different sources: air, milking equipment, feed, soil, feces and grass $(1,7)$. The number and types of microorganisms in milk instantly after milking are affected by factors such as animal and equipment cleanliness, season, feed and animal health (8). It is hypothesized that the various ways in feeding and housing strategies of cows may influence the microbial quality of milk (7). The water used for rinsing milking machine and equip-

${ }^{\ddagger}$ Corresponding Author: Mailing address. Md. Aftab Uddin, Department of Microbiology, Stamford University Bangladesh, 51 Siddeswari Road, Dhaka 1217, Bangladesh; E-mail: aftab_mb12@yahoo.com. ment may also be responsible for the presence of high load of micro-organisms including pathogens in raw milk (9). Among the microbial populations, Gram-negative bacteria usually account for more than $90 \%$ in cold raw milk that has been stored including psychrotrophic species of Pseudomonas, Achromobacter, Aeromonas, Serratia, Alcaligenes, Chromobacterium, Flavobacterium and Enterobacter (10-13). The presence of indicator bacteria and some other bacteria in lesser number determines the safety and quality of milk and milk products (8). Therefore in order to protect the public health, microbiological assessments have an important role to play in the dairy industry. This will also reduce economic losses by the early detection of insufficient processing, packaging or refrigeration.

The milkmen in Bangladesh, mostly produce milk in non-standardized way and usually supply to the consumers from the urban and rural areas $(1,14)$. As a consequence of adulteration in milk both the dilution in the amount of milk solids as well as the introduction of various pathogens takes place. So it is very much imperative to process the milk in such a way so that it assures the safety as well as the wholesomeness of the milk quality is maintained $(1,2)$. The preamble of pasteurized and Ultra high temperature (UHT) processed milk in Bangladesh is not very new and proved to be very much well-liked among consumers. Recently microbiological status of various types of treated milk is gaining a matter of great 
interest (1). Due to the treatment process, high microbial load in milk is unexpected in the pasteurized or the UHT milk. After the date of manufacture, the recommended date of consumption for the pasteurized and the UHT milk is 7 days and 6 months, respectively. But the poor initial milk quality, defective processing or problem in preservation at the consumer side may deteriorate milk quality before the original date of expiry (15). The Bangladesh Standards and Testing Institution (BSTI) has set various chemical and sanitary requirements for the pasteurized milk (16).

This study reveals the microbiological standards of raw and processed milk samples from different areas in Bangladesh. The findings of the study will be an indication about the initial bacterial loads in raw milk samples as well as how much safe is the processed milk for consumptions. Besides, different regulatory bodies may also realize the importance of frequent inspection of the market milks to ensure whether they meet the minimum microbiological standards for the mass people.

\section{MATERIALS AND METHODS}

Working place and study period. All the experiments of this work were carried out in the Microbiology Laboratory, Department of Quality Control (QC), Akij Food \& Beverage ltd., Bangladesh from September 2013 to February 2014.

Sample Collection. In this study, raw milk samples were purchased from local daily markets and the processed milks were bought from different shops in Dhaka city. A total of 46 samples were studied. 22 raw milk (designated as R-1 to R-22) samples were collected from different vendors. Of the remaining 24, 12 (designated as P-1 to P-12) were pasteurized milk and the rest 12 (U-1 to U-12) were UHT milk of different brands. All the samples were aseptically collected using a sample collector ice box at $4{ }^{\circ} \mathrm{C}$ and were transported to the laboratory without delay.

Isolation and estimation of microorganisms from milk samples. Serial dilutions of samples were made up to $10^{-7}$ in sterile normal saline. The bacterial count was then performed by standard method $(1,17)$.

Total Viable Bacterial Count (TVBC) and Total Coliform Count (TCC). The total viable bacterial count was carried out by the spread plate technique. The sample $(0.1 \mathrm{ml})$ of each dilution was taken onto each sterile petridish and evenly spread on the solid nutrient medium and incubated at $37{ }^{\circ} \mathrm{C}$ for 24 hours. The plates were screened for the presence of discrete colonies after incubation period and the actual numbers of bacteria were estimated as colony forming unit in per $\mathrm{ml}(\mathrm{cfu} / \mathrm{ml})$. Then the results per dilution were recorded. Quantitative analysis for the presence or absence of specific microorganisms was done by plating on selective media. Total coliform count (TCC) was done using MacConkey agar medium (1). All the viable counts were the average of at least three independent experiments. Bacterial isolates were then identified according to the Bergey's manual of determinative bacteriology $(1,18)$.

\section{RESULTS AND DISCUSSION}

Total Viable Bacterial Count (TVBC). The total viable bacterial count is the number of bacteria in a sample that can grow and form countable colonies on Nutrient agar after being held at $37{ }^{\circ} \mathrm{C}$ for 24 hours. The results of bacterial distribution of the raw milk samples are presented in Table 1. All the raw milk samples had high bacterial load which ranged from $5.2 \times 10^{8}$ to $1.3 \times 10^{7} \mathrm{cfu} / \mathrm{ml}$. The most frequent cause of high bacterial load is normally as a result of poor cleaning of the milking system. Bacterial count may be
TABLE 1. Microbiological quality analysis of different raw milk samples collected from different city

\begin{tabular}{ccccc}
\hline $\begin{array}{c}\text { Sample } \\
\text { no. }\end{array}$ & Location & $\begin{array}{c}\text { Collection } \\
\text { point }\end{array}$ & $\begin{array}{c}\text { TVBC } \\
(\mathrm{cfu} / \mathrm{ml})\end{array}$ & $\begin{array}{c}\text { TCC } \\
(\mathrm{cfu} / \mathrm{ml})\end{array}$ \\
\hline R-01 & & Mallikpur & $2.2 \times 10^{8}$ & $1.3 \times 10^{4}$ \\
R-02 & Rohanpur & $1.5 \times 10^{7}$ & $1.1 \times 10^{5}$ \\
R-03 & Rajshahi & Noyagola & $2.4 \times 10^{7}$ & $2.0 \times 10^{5}$ \\
R-04 & & Dima & $1.1 \times 10^{8}$ & $1.0 \times 10^{4}$ \\
R-05 & & Nachol & $1.3 \times 10^{7}$ & $2.1 \times 10^{5}$ \\
\hline R-06 & & Bera & $1.2 \times 10^{8}$ & $2.4 \times 10^{4}$ \\
R-07 & & Talgachi & $1.6 \times 10^{7}$ & $1.6 \times 10^{5}$ \\
R-08 & & Sujanagar & $2.2 \times 10^{7}$ & $1.9 \times 10^{5}$ \\
R-09 & & Nakalia & $1.4 \times 10^{8}$ & $2.7 \times 10^{4}$ \\
R-10 & & Jogatola & $5.2 \times 10^{8}$ & $3.0 \times 10^{4}$ \\
R-11 & Pabna & Nouga & $3.5 \times 10^{7}$ & $1.4 \times 10^{5}$ \\
R-12 & Demra & $2.6 \times 10^{8}$ & $1.7 \times 10^{4}$ \\
R-13 & & Austomonisha & $3.3 \times 10^{7}$ & $1.9 \times 10^{4}$ \\
R-14 & & Murgram & $4.7 \times 10^{7}$ & $2.3 \times 10^{5}$ \\
R-15 & & Bhangura & $2.9 \times 10^{8}$ & $1.5 \times 10^{4}$ \\
R-16 & & Mohanpur & $3.6 \times 10^{7}$ & $1.8 \times 10^{5}$ \\
R-17 & & Begamari & $3.2 \times 10^{8}$ & $2.5 \times 10^{5}$ \\
\hline R-18 & & Shirkandi & $4.2 \times 10^{8}$ & $2.7 \times 10^{5}$ \\
R-19 & \multirow{2}{*}{ Khustia } & Kollanpur & $3.1 \times 10^{7}$ & $3.3 \times 10^{4}$ \\
R-20 & Mohendrapur & $6.0 \times 10^{7}$ & $4.2 \times 10^{4}$ \\
R-21 & & Surjonagar & $2.6 \times 10^{8}$ & $3.6 \times 10^{4}$ \\
R-22 & & & & \\
\hline & & &
\end{tabular}

TVBC $=$ Total viable bacterial count TCC $=$ Total coliform count

high due to milking dirty udders, maintaining an unclean milking and housing environment and failing to rapidly cool milk to less than $40{ }^{\circ} \mathrm{F}$ (19). Aaku et al. (20) and Arenas et al. (21) have found $5.5 \times 10^{6} \mathrm{cfu} / \mathrm{ml}$ and $10^{6}$ to $10^{7} \mathrm{cfu} / \mathrm{ml}$ of the total number of microorganisms in pooled raw milk, respectively, which were comparatively lower than this experiment. Hossain et al. (2) conducted an experiment in India and found that the bacterial count in raw milk ranged from $1.75 \times 10^{6}$ to $1.22 \times 10^{8} \mathrm{cfu} / \mathrm{ml}$.

There are several reasons for the occurrence of bacterial contamination in the pasteurized milk samples such as defect in pasteurization machinery, to survive even after pasteurization, and contamination in the post-pasteurized process due to poor processing and handling conditions and/or maintenance of substandard hygienic practices by working personnel. The TVBC (total viable bacterial count) of the pasteurized milk samples in this study was ranged from $1.1 \times 10^{2}$ to $1.8 \times 10^{3} \mathrm{cfu} / \mathrm{ml}$ (Table 2 ), slightly lower than that recommended by BSTI and USPHS (not exceeding $20,000 \mathrm{cfu} / \mathrm{ml})(16,22)$. Hossain et al. (2) found the bacterial count in pasteurized milk samples were in between $7.5 \times 10^{7}$ to $1.24 \times 10^{8} \mathrm{cfu} / \mathrm{ml}$. interestingly, three milk samples (P-6, P-10, P-12) showed no growth at all.

According to the definition of UHT process, presence of bacteria in UHT milk should be minimal or not at all (23). As expected, TVBC of each of the UHT-processed milks in this study was nil. This was an indication that there might be no problem in UHT process. The reasons for the presence of bacteria in UHT milk may be due to 
TABLE 2. Microbiological quality analysis of different pasteurized milk samples

\begin{tabular}{ccc}
\hline Sample no. & TVBC $(\mathrm{cfu} / \mathrm{ml})$ & TCC $(\mathrm{cfu} / \mathrm{ml})$ \\
\hline P-01 & $1.0 \times 10^{3}$ & 0 \\
P-02 & $1.4 \times 10^{2}$ & 0 \\
P-03 & $1.8 \times 10^{3}$ & 0 \\
P-04 & $2.1 \times 10^{2}$ & 0 \\
P-05 & $1.2 \times 10^{2}$ & 0 \\
P-06 & 0 & 0 \\
P-07 & $1.6 \times 10^{3}$ & 0 \\
P-08 & $2.3 \times 10^{2}$ & 0 \\
P-09 & $1.1 \times 10^{2}$ & 0 \\
P-10 & 0 & 0 \\
P-11 & $1.3 \times 10^{3}$ & 0 \\
P-12 & 0 & 0 \\
\hline
\end{tabular}

TVBC $=$ Total viable bacterial count, $\mathrm{TCC}=$ Total coliform count

milk quality, sanitation of process plant, status of packaging material and also the process of handling (24). So the absence of bacteria in UHT process milk reveals the fact that the milk company produced high quality of UHT milk.

Total Coliform Count. The presence of Escherichia coli (one of the member of coliform bacteria) in milk is a common indicator of fecal contamination. Biochemical test were carried out for confirming the presence for coliform (Table 3). Average coliform count in the raw milks ranged from $2.0 \times 10^{5}$ to $1.0 \times 10^{4}$ $\mathrm{cfu} / \mathrm{ml}$ (Table 1) which was higher than that obtained by Saitanu et al. (25), who found TCC (total coliform count) of $<1000 \mathrm{cfu} / \mathrm{ml}$. However, TCC obtained in the study of Srari et al. (26) varied from less than 30 to $2.08 \times 10^{7} \mathrm{cfu} / \mathrm{ml}$ in raw milk.

E. coli was isolated from 14 out of 22 raw milk samples. In an another study by Uddin et al. (8), the range of total coliform count was from $8 \times 10^{6} \mathrm{cfu} / \mathrm{ml}$ to $1.0 \times 10^{4} \mathrm{cfu} / \mathrm{ml}$. Several authors previously have reported about the higher prevalence of $E$. coli. In Egypt, Aly and Galal, (27) reported the presence of $E$. coli in raw milk. Reasons for higher coliforms counts in raw milk may be as a result of poor hygiene, contaminated water, unsanitary milking practices, and improperly washed and maintained equipment $(1,28)$.

Coliform bacteria are supposed to be absent in pasteurized milk as they can't survive the pasteurization temperature. Because of the defect in pasteurization process or post pasteurization contamination which includes contamination in packaging materials, defects in pipe lines, TCC may be detected in the pasteurized milk samples $(15,28)$. In this study as expected, the TCC was not found in the different pasteurized milk samples. According to USPHS not over 10 colonies is acceptable for 'Grade A' pasteurized milk (22). These results of detecting the coliform bacteria test indicates that processed milk available in Bangladesh are of good quality and will not cause health risk to consumers.

\section{CONCLUSION}

From the present study, it can be concluded that the microbiological quality of most of the raw milk samples collected from different areas of Dhaka city were not satisfactory as indicated by their high bacterial loads and presence of coliform bacteria. But after pasteurization and UHT treatment they were found to be safe for the consumers. Even after this, proper refrigeration temperature should be maintained particularly in case of pasteurized milk samples.

\section{ACKNOWLEDGEMENTS}

The authors thank the Microbiology Laboratory of Quality Control (QC) Department, Akij Food \& Beverage Itd. to facilitate the experiments.

\section{REFERENCES}

1. Marjan, S., K. K. Das, S. K. Munshi, and R. Noor. 2014. Drug-resistant bacterial pathogens in milk and some milk products. Nutn. Food Sci. 44 (3): 241-248.

2. Hossain, T. J., K. Alam and D. Sikdar. 2010. Chemical and microbiological quality assessment of raw and processed liquid market milks of Bangladesh. Res. J. Dairy Sci. 4 (4): 28-34

3. Haug, A., A. T. Hostmark and O. M. Harstad. 2007. Bovine milk in human nutrition - A review. Lipids He alth. Dis. 6: 25

4. Kim, H., et al. 1983. Off-tastes in raw and reconstituted milk. FAO Animal Production and Health Paper.

5. OECD. 2005. Dairy policy reform and trade liberalization. Organization for Economic Co-operation \& Development Publishing, Paris, France.

6. Tolle, A. 1980. The microflora of the udder: Factors influencing the bacteriological quality of raw milk. International Dairy Federation Bulletin.

7. Coorevits, A., et al. 2008. Comparative analysis of the diversity of aerobicspore-forming bacteria in raw milk from organic and conventional dairy farms. Appl. Microbiol. 31 (2): 126-140.

8. Uddin, M. A., H. M. M. U. Haque, and R. Noor. 2011. Isolation and Identification of pathogenic Escherichia coli, Klebsiella spp. and Staphylococcus spp. in raw milk samples collected from different areas of Dhaka city, Bangladesh. Stamford J. Microbiol. 1 (1): 19-23

9. Bramley, A. J., and C. H. McKinnon. 1990. The microbiology of raw milk, p. 163-208. In R. K. Robinson (ed.), Dairy Microbiology. Elsevier Science Publishers, London.

10. Armesto, M. R. G., and A. D. Sutherland. 1997. Temperature characterization of psychrotrophic and mesophilic Bacillus species from milk. J. Dairy Res. 64: 261-270.

TABLE 3. Results of biochemical tests

\begin{tabular}{|c|c|c|c|c|c|c|c|c|c|c|c|c|}
\hline \multirow[t]{2}{*}{ Isolate } & \multicolumn{4}{|c|}{ TSI } & \multirow[t]{2}{*}{ Motility } & \multirow{2}{*}{$\begin{array}{c}\text { Indole } \\
\text { Production }\end{array}$} & \multirow[t]{2}{*}{ MR } & \multirow[t]{2}{*}{$\mathrm{VP}$} & \multirow{2}{*}{$\begin{array}{c}\text { Citrate } \\
\text { utilization }\end{array}$} & \multirow[t]{2}{*}{ Catalase } & \multirow[t]{2}{*}{ Oxidase } & \multirow{2}{*}{$\begin{array}{l}\text { Identified } \\
\text { organism }\end{array}$} \\
\hline & Slant & Butt & Gas & $\mathrm{H}_{2} \mathrm{~S}$ & & & & & & & & \\
\hline 1 & $\mathrm{~A}$ & A & + & - & + & + & + & - & - & ND & ND & E. coli \\
\hline
\end{tabular}

$\mathrm{A}=$ Acidic reaction; $\mathrm{K}=$ Alkaline reaction $; \mathrm{MR}=$ Methyl red; $\mathrm{VP}=$ Voges-Proskauer; $\mathrm{ND}=$ Not done $+=$ Positive $;-=\mathrm{Negative}$ 
11. Sørhaug, T., and L. Stepaniak. 1997. Psychrotrophs and their enzymes in milk and dairy products: quality aspects. Trends in Food Sci. Technol. 8: $35-40$.

12. Ryser. 1999. Microorganisms of importance in raw milk. Michigan Dairy Review 8: 7-9.

13. Martins, M. L., et al. 2006. Genetic diversity of Gram-negative proteolytic, psychrotrophic bacteria isolated from refrigerated raw milk. Int. J. Food Microbiol. 111: 144-148.

14. Khan, M. T. G., et al. 2008. Physical and microbial qualities of raw milk collected from Bangladesh agricultural university dairy farm and the surrounding villages. Bangladesh J. Vet. Med. 6 (2): 217-221.

15. Dey, S., and M. H. Karim. 2013. Study on physicochemical and microbial quality of available raw, pasteurized and UHT milk during preservation. Int. J. Sci. Invent. Today 2 (2): 150-157.

16. Bangladesh Standards and Testing Institution. 2002. Bangladesh standard: Specification for pasteurized milk. Bangladesh Standards and Testing Institution, Tejgaon Industrial Area, Dhaka.

17. International Commission on Microbiological Specifications for Foods. 1978. Microorganisms in foods. In Microbial ecology of foods. Academic Press, New York.

18. Buchanan, R. E., and N. E. Gibbon. 1984. Bergey's manual of determminative bactariology, Baltimore. William and Wilkins Co., New York.

19. Saxena, M., and P. Rai. 2013. Microbiological and chemical analysis of raw, pasteurized and UHT milk during preservation in India. Int. J. Chem. Tech. Res. 5 (6): 2804-2809.
20. Aaku, E. N., E. K. Collinson, B. A. Gashe, and S. Mpuchane. 2004. Microbiological quality of milk from two processing plants in Gaborone Botswana. Food Control 15: 181-186.

21. Arenas, R. L., et al. 2004. Microbiological and physico-chemical changes in Genestoso cheese, a Spanish acid curd variety, throughout ripening. Food Control 154: 271-279

22. Jay, J. M. 2003. Modern Food Microbiology, $4^{\text {th }}$ ed. CBS Publishers and Distributor, India.

23. Hassan, A., I. Amjad, and S. Mahmood. 2009. Microbiological and physicochemical analysis of different UHT milk available in local market. As. J. Food Ag. Ind. 2 (3): 434-447

24. Tekinsen, K. K., M. Elmali, and Z. Ulukanli. 2007. Microbiological quality of UHT milk consumed in Turkey. Internet J. Food Safety 7: 45-48.

25. Saitanu, I. A., et al. 1996. Microbiological quality of raw cow milk. Thai J. Vet. Med. 26 (3): 193-214.

26. Sraïri, M. T., J. Moudnib, L. Rahho, and A. Hamama. 2006. How do milking conditions affect the hygienic quality of raw milk? Case study from Moroccan dairy farms. Livestock Research for Rural Development 18 (7): 97.

27. Aly, S. A., and E. A. Galal. 2002. Effect of milk pretreatment on the keeping quality of Domiati cheese. Pak. J. Nutr. 1: 132-136.

28. California Department of Food and Agriculture. 2008. New Coliform standard for milk sold to consumers. California Department of Food and Agriculture. 